\title{
Facing Southern Ocean warming: Temperature effects on whole animal performance of Antarctic krill (Euphausia superba)
}

\author{
Katharina Michael $^{\mathrm{a}, *}$, Lavinia A. Suberg ${ }^{\mathrm{d}}$, Wiebke Wessels ${ }^{\mathrm{a}}$, So Kawaguchi ${ }^{\mathrm{b}, \mathrm{c}}$, \\ Bettina Meyer ${ }^{\mathrm{a}, \mathrm{d}}$, e \\ ${ }^{a}$ Institute for Chemistry and Biology of the Marine Environment, Carl von Ossietzky University of Oldenburg, Carl-von-Ossietzky-Straße 9-11, 26111, Oldenburg, \\ Germany \\ ${ }^{\mathrm{b}}$ Australian Antarctic Division, Department of Agriculture, Water and the Environment, 203 Channel Highway, Kingston, Tasmania, 7050, Australia \\ ${ }^{\mathrm{c}}$ Antarctic Climate and Ecosystems Cooperative Research Centre, 20 Castray Esplanade, Hobart, Tasmania, 7000, Australia \\ ${ }^{\mathrm{d}}$ Alfred Wegener Institute Helmholtz Centre for Polar and Marine Research, Scientific Division Polar Biological Oceanography, Am Handelshafen 12, 27570, \\ Bremerhaven, Germany \\ ${ }^{\mathrm{e}}$ Helmholtz Institute for Functional Marine Biodiversity at the University of Oldenburg (HIFMB), Ammerländer Heerstraße 231, 26129, Oldenburg, Germany
}

\section{A R T I C L E I N F O}

\section{Keywords:}

Antarctic krill

Euphausia superba

climate change

temperature

whole animal performance

\begin{abstract}
A B S T R A C T
The ongoing environmental changes in the Southern Ocean may cause a dramatic decrease in habitat quality. Due to its central position in the food web, Antarctic krill (Euphausia superba) is a key species of the marine Antarctic ecosystem. It is therefore crucial to understand how increasing water temperatures affect important krill life-cycle processes. Here, a long-term (August - March) laboratory acclimation experiment at different temperature scenarios $\left(0.5^{\circ} \mathrm{C}, 1.5^{\circ} \mathrm{C}, 2.5^{\circ} \mathrm{C}, 3.5^{\circ} \mathrm{C}, 5^{\circ} \mathrm{C}, 7^{\circ} \mathrm{C}\right)$ was performed and the effects of elevated temperatures on whole animal parameters $\left(\mathrm{O}_{2}\right.$ consumption, body length, length of the digestive gland) were analyzed. The response of krill oxygen consumption to different experimental temperatures differed between acute/short-term and long-term acclimation. After 8 months, krill oxygen consumption remained unchanged up to temperatures of $3.5^{\circ} \mathrm{C}$ and was significantly higher at temperatures $>3.5^{\circ} \mathrm{C}$. Krill acclimated to temperatures $\geq 3.5^{\circ} \mathrm{C}$ were significantly smaller at the end of the experiment. Limited food intake and/or conversion may have contributed to this effect, especially pronounced after the onset of the reproductive period. In addition, the seasonal growth pattern in males differed from that of females. Together, our findings indicate that warming Southern Ocean waters are likely to increase metabolic rate in krill, possibly altering the amount of energy available for other important life-cycle processes, a finding directly related to future population dynamics and fisheries management.
\end{abstract}

\section{Introduction}

The Southern Ocean habitat is subject to ongoing environmental changes which may cause a dramatic decrease in habitat quality (Flores et al., 2012). Warming in the Southern Ocean is not spatially uniform but trends can be identified in some regions (Whitehouse et al., 2008; Meredith et al., 2019). Summer water temperatures in the upper $100 \mathrm{~m}$ around South Georgia have increased by $0.9^{\circ} \mathrm{C}$ since 1925 (Whitehouse et al., 2008) and surface waters west of the Antarctic Peninsula have increased by $1{ }^{\circ} \mathrm{C}$ during the second half of the 20th century (Meredith and King, 2005). Bottom waters around Antarctica also warmed detectably over the last decades (Rhein et al., 2013) and future scenarios predict that observed Southern Ocean warming trends will continue (Meredith et al., 2019).

Antarctic krill, Euphausia superba ("krill" hereafter), is a key species of the Southern Ocean ecosystem due to its central position in the food web. Krill also supports a major commercial fishery, which has consistently been the largest fishery (by tonnage) in the Southern Ocean since its beginnings in the 1970s (Nicol et al., 2012; Nicol and Foster, 2016). Studies on population dynamics and recruitment under predicted ocean warming scenarios indicate declining abundances and biomass of krill and/or poleward relocations of populations if surface warming continues (e.g. Atkinson et al., 2004; Hill et al., 2013; Piñones and Fedorov, 2016; Atkinson et al., 2019; Veytia et al., 2020). So far, the response of

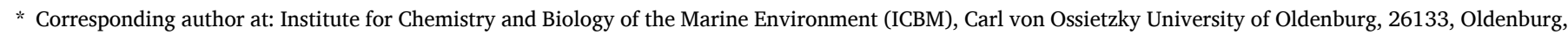
Germany.

E-mail address: katharina.michael@uol.de (K. Michael).
} 
the different factors affecting circumpolar krill populations has not led to sufficient predictive power, due to the regional variability of climate change effects in the Southern Ocean (Larsen et al., 2014). In addition, physiological and behavioral responses may also modify the effects (Larsen et al., 2014).

Studies providing insight into the response of physiological processes of Antarctic krill to climate-induced environmental changes are scarce (Meyer and Teschke, 2016), compromising the accuracy of predictions on how this species may respond to future climate change. However, to determine the sensitivity of a species to climate change, it is crucial to understand how increasing water temperatures affect the physiological processes on the background of the species' life cycle (Meyer, 2010b). As an Antarctic marine species, krill have evolved in a very cold and stable environment for at least 10 million years (Peck, 2005). Consequently, they are adapted to a very narrow temperature range (Buchholz and Saborowski, 2000) and can be considered as stenothermal, i.e. being unable to tolerate large oscillations in environmental temperatures (Peck, 2005). Although krill were shown to tolerate temperatures $\geq 10$ ${ }^{\circ} \mathrm{C}$ during short-term exposures (McWhinnie and Marciniak, 1964; Cascella et al., 2015; Tarling, 2020), it seems unlikely that temperatures higher than $3.5^{\circ} \mathrm{C}$ are tolerable over longer time scales (Flores et al., 2012).

Krill oxygen consumption rates, previously measured in laboratory and field studies were comprised mostly of acute and short-term experiments with acclimation times varying in the range of hours to a few days. In most studies, the response of krill oxygen consumption to temperature was found to be nearly independent within the thermal ranges of their natural environment, although results differ with respect to the lower and upper border of these ranges (McWhinnie and Marciniak, 1964; Segawa et al., 1979; Opalinski, 1991; Ngan et al., 1997). In contrast, Hirche (1984) and Tarling (2020) showed that krill oxygen consumption increased with temperature, at least up to $5.5{ }^{\circ} \mathrm{C}$. The different patterns observed may be related to different methodologies, differences in krill size and/or stage, as well as different habitats investigated (Ngan et al., 1997). Environmental temperatures were also shown to influence the seasonal cycle of krill growth along with food quality and quantity (e.g. Poleck and Denys, 1982; Atkinson et al., 2006; Kawaguchi et al., 2006, 2007a; Wiedenmann et al., 2008; Brown et al., 2010). The optimum temperature for krill growth was suggested to lie between $0.5{ }^{\circ} \mathrm{C}$ and $1{ }^{\circ} \mathrm{C}$ and growth rates declined at temperatures between $3{ }^{\circ} \mathrm{C}$ and $4{ }^{\circ} \mathrm{C}$ (Atkinson et al., 2006; Brown et al., 2010). These results imply that changing water temperatures may have a profound impact on krill physiology. As the krill's life cycle is generally timed closely to their highly seasonal environment, any changes in the environment may have the potential to disrupt this delicate interplay (Teschke et al., 2011; Meyer and Teschke, 2016). In addition, temperature itself may act as an important environmental cue driving this daily and/or seasonal interplay (Rensing and Ruoff, 2002).

Due to the central role of krill in the Southern Ocean ecosystem, the Southern Ocean food web is particularly vulnerable to any perturbations of krill populations (de Santana et al., 2013). It is therefore crucial to identify effective processes determining the sensitivity and adaptability of this species to a warming Southern Ocean, to not only enable realistic predictions of future population dynamics but also adapt ecosystem-based management approaches for krill fisheries (Flores et al., 2012; Meyer et al., 2020). However, relying on field experiments only limits the ability to understand the magnitude of the effects (Brown et al., 2010). Field and laboratory data need to be combined to obtain a higher experimental resolution as well as a process-based understanding of the effects of elevated water temperatures on krill physiology. We therefore analyzed whole animal performance of Antarctic krill by investigating oxygen consumption rates, changes in mean body length as well as length of the digestive gland, as a proxy for feeding activities, in a long-term (August to March) laboratory experiment at different experimental temperature regimes according to the model projections for mean changes in Southern Ocean and global ocean sea surface temperatures in the upcoming century (Bopp et al., 2013; IPCC, 2013; Rintoul et al., 2018; IPCC, 2019). In addition, experimental temperatures of $5{ }^{\circ} \mathrm{C}$ and $7{ }^{\circ} \mathrm{C}$ were applied in order to generate a more thorough understanding of the responses of Antarctic krill to changing water temperatures.

\section{Material and Methods}

\subsection{Field sampling and laboratory maintenance of krill}

Antarctic krill (Euphausia superba) were caught in December 2016 off East Antarctica (64 $\left.37^{\prime} 57.1^{\prime \prime} \mathrm{S} 111^{\circ} 00^{\prime} 13.0^{\prime \prime} \mathrm{E}\right)$ in the upper 5-15 $\mathrm{m}$ of the water column during voyage V2 16/17 of RSV Aurora Australis using a targeted RMT8 trawl. Upon capture, all krill were immediately transferred to holding tanks $(1,700 \mathrm{~L})$ located in a constant-temperature room at $0{ }^{\circ} \mathrm{C}$ and supplied with a continuous flow of chilled seawater $(10 \mathrm{~L}$ $\min ^{-1}, 0^{\circ} \mathrm{C}, \mathrm{NH}_{4}^{+}$-free). Dead krill and moults were removed daily. After arrival in Hobart (Tasmania) krill were delivered to the Australian Antarctic Division (AAD) in Kingston and transferred to 1,700 L holding tanks. Temperature in the tanks was maintained at $0.5{ }^{\circ} \mathrm{C}$. Water was recirculated through an array of mechanical and biological filters while continuously monitored for quality (Kawaguchi et al., 2010). A PC-controlled timer and dimming system (winDIM v4.0e, EEE, Portugal) ensured natural Southern Ocean light conditions, running a sinusoidal annual cycle with monthly variations of photoperiod and light intensity assuming continuous light and a maximum of 100-lux light intensity at the surface of the tank (equal to $1 \%$ light penetration to $30 \mathrm{~m}$ depth during austral summer midday at $66^{\circ} \mathrm{S}$ ) (Kawaguchi et al., 2010). Due to logistic reasons, monthly variations in light conditions were shifted backwards by one month. In the results section, time references therefore refer to the respective Southern Ocean light conditions prevailing, i. e. September will be indicated as ("Antarctic") August and so on. Krill were fed daily with a mix of live laboratory-cultured algae which has been successfully used in several experiments at the AAD prior to this study and guarantees low mortality and high feeding rates in long-term laboratory maintenance of krill (Kawaguchi et al., 2010). Dead krill and moults were removed daily.

\subsection{Experimental design and sampling}

Different experimental temperature regimes were applied according to the model projections for mean changes in Southern Ocean and global ocean sea surface temperatures in the upcoming century (Bopp et al., 2013; IPCC, 2013; Rintoul et al., 2018; IPCC, 2019): $0.5{ }^{\circ} \mathrm{C}$ served as control temperature, $1.5^{\circ} \mathrm{C}\left(+\sim 1{ }^{\circ} \mathrm{C}\right.$; global and Southern Ocean, RCP 2.6), $2.5{ }^{\circ} \mathrm{C}\left(+\sim 2{ }^{\circ} \mathrm{C}\right.$; Southern Ocean, RCP 8.5$)$ and $3.5^{\circ} \mathrm{C}\left(+\sim 3{ }^{\circ} \mathrm{C}\right.$; global, RCP 8.5). Additionally, experimental temperatures of $5^{\circ} \mathrm{C}(+4.5$ $\left.{ }^{\circ} \mathrm{C}\right)$ and $7{ }^{\circ} \mathrm{C}\left(+6.5^{\circ} \mathrm{C}\right)$ were applied. For each experimental temperature, the experimental setup comprised four cylindrical $60 \mathrm{~L}$ tanks (Tanks A-D) placed in an individual jacket tank (referred to as one "cluster" in the following). Continuous inflow of filtered and chilled seawater $\left(30 \mathrm{~L} \mathrm{~h}^{-1}\right)$ ensured a permanent water exchange. The inflowing water temperature was monitored by a controller unit for each tank and regulated by heating rods. This setup allowed the adjustment of temperature for each cluster individually within a range of $\pm 0.1{ }^{\circ} \mathrm{C}$. All tanks were aerated with filtered air. Light regime was controlled by the same PC software as in the holding system (see above). Prior to the start of the experiment on September 17, 2017 (= Antarctic August; see above), krill were randomly transferred from the holding system to the experimental tanks until each tank held 96 individuals. After one week of acclimation at control temperature $\left(0.5^{\circ} \mathrm{C}\right)$, water temperature was gradually increased by $1{ }^{\circ} \mathrm{C}$ per day until target temperatures were reached within each cluster except of the control cluster. Throughout the whole experimental phase, krill were fed daily with a mix of live laboratory-cultured algae ( $1 \mathrm{~L}$ per experimental tank) of the pennate diatom Phaeodactylum tricornutum (final concentration of $1.5 \times 10^{4}$ 
Table 1

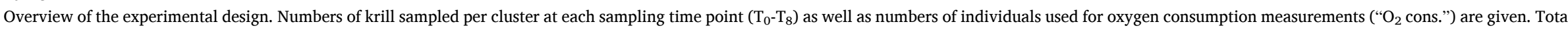

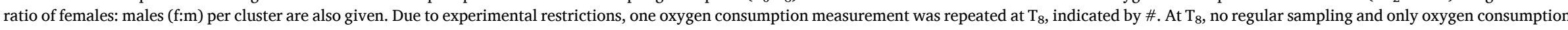
measurements were performed. Experimental days between samplings/experimental days passed since the start of the experiment (September 17, 2017) are indicated in italic.

\begin{tabular}{|c|c|c|c|c|c|c|c|c|c|c|}
\hline \multirow[b]{2}{*}{ Cluster } & \multirow[b]{2}{*}{$\begin{array}{l}\text { Total } \mathrm{n} / \text { cluster } \\
(n / \operatorname{tank})\end{array}$} & \multicolumn{9}{|c|}{ Sampling timepoint (T) } \\
\hline & & $\begin{array}{l}\mathrm{T}_{0}-24 \text { hours } \\
\text { September } \\
\text { Antarctic } \\
\text { August }\end{array}$ & $\begin{array}{l}\mathrm{T}_{1}-4 \text { wks/month } 1 \\
\text { October } \\
\text { Antarctic } \\
\text { September }\end{array}$ & $\begin{array}{l}\mathrm{T}_{2}-\text { month } 2 \\
\text { November } \\
\text { Antarctic } \\
\text { October }\end{array}$ & $\begin{array}{l}\mathrm{T}_{3}-\text { month } 3 \\
\text { December } \\
\text { Antarctic } \\
\text { November }\end{array}$ & $\begin{array}{l}\mathrm{T}_{4} \text { - month } 4 \\
\text { January } \\
\text { Antarctic } \\
\text { December }\end{array}$ & $\begin{array}{l}\mathrm{T}_{5}-\text { month } 5 \\
\text { February } \\
\text { Antarctic } \\
\text { January }\end{array}$ & $\begin{array}{l}\mathrm{T}_{6}-\text { month } 6 \\
\text { March } \\
\text { Antarctic } \\
\text { February }\end{array}$ & $\begin{array}{l}\mathrm{T}_{7}-\text { month } 7 \\
\text { April } \\
\text { Antarctic } \\
\text { March }\end{array}$ & $\begin{array}{l}\left(\mathrm{T}_{8}\right)-\text { month } 8 \\
\text { May } \\
\text { Antarctic } \\
\text { April }\end{array}$ \\
\hline $0.5^{\circ} \mathrm{C}$ & $\begin{array}{l}384 \\
(96 / \operatorname{tank} A 1-D 1) \\
\text { f:m: } 184: 72\end{array}$ & $\begin{array}{l}\mathrm{n}=32 \\
\mathrm{O}_{2} \text { cons.: } \mathrm{n}=8 \\
(1)\end{array}$ & $\begin{array}{l}\mathrm{n}=32 \\
\mathrm{O}_{2} \text { cons.: } \mathrm{n}=8 \\
(27 / 28)\end{array}$ & $\begin{array}{l}\mathrm{n}=32 \\
(30 / 58)\end{array}$ & $\begin{array}{l}\mathrm{n}=32 \\
(28 / 86)\end{array}$ & $\begin{array}{l}\mathrm{n}=32 \\
(29 / 115)\end{array}$ & $\begin{array}{l}\mathrm{n}=32 \\
(28 / 143)\end{array}$ & $\begin{array}{l}\mathrm{n}=32 \\
(23 / 166)\end{array}$ & $\begin{array}{l}\mathrm{n}=32 \\
(27 / 193)\end{array}$ & $\begin{array}{l}\mathrm{O}_{2} \text { cons.: } \mathrm{n}=2 * 8^{\#} \\
(51 / 244)\end{array}$ \\
\hline $1.5^{\circ} \mathrm{C}$ & $\begin{array}{l}384 \\
(96 / \operatorname{tank} A 2-D 2) \\
\text { f:m: 196:60 }\end{array}$ & $\begin{array}{l}\mathrm{n}=32 \\
\mathrm{O}_{2} \text { cons.: } \mathrm{n}=8 \\
\text { (1) }\end{array}$ & $\begin{array}{l}\mathrm{n}=32 \\
\mathrm{O}_{2} \text { cons.: } \mathrm{n}=8 \\
(27 / 28)\end{array}$ & $\begin{array}{l}\mathrm{n}=32 \\
(28 / 58)\end{array}$ & $\begin{array}{l}\mathrm{n}=32 \\
(28 / 86)\end{array}$ & $\begin{array}{l}\mathrm{n}=32 \\
(29 / 115)\end{array}$ & $\begin{array}{l}\mathrm{n}=32 \\
(28 / 143)\end{array}$ & $\begin{array}{l}\mathrm{n}=32 \\
(23 / 166)\end{array}$ & $\begin{array}{l}\mathrm{n}=32 \\
(27 / 193)\end{array}$ & $\begin{array}{l}\mathrm{O}_{2} \text { cons.: } \mathrm{n}=8 \\
(53 / 246)\end{array}$ \\
\hline $2.5^{\circ} \mathrm{C}$ & $\begin{array}{l}384 \\
\text { (96/tank A3-D3) } \\
\text { f:m: 194:61 }\end{array}$ & $\begin{array}{l}\mathrm{n}=32 \\
\mathrm{O}_{2} \text { cons.: } \mathrm{n}=8 \\
\text { (1) }\end{array}$ & $\begin{array}{l}\mathrm{n}=32 \\
\mathrm{O}_{2} \text { cons.: } \mathrm{n}=8 \\
(27 / 28))\end{array}$ & $\begin{array}{l}\mathrm{n}=32 \\
(27 / 55)\end{array}$ & $\begin{array}{l}\mathrm{n}=32 \\
(29 / 84)\end{array}$ & $\begin{array}{l}\mathrm{n}=32 \\
(28 / 112)\end{array}$ & $\begin{array}{l}\mathrm{n}=32 \\
(28 / 140)\end{array}$ & $\begin{array}{l}\mathrm{n}=32 \\
(23 / 163)\end{array}$ & $\begin{array}{l}\mathrm{n}=32 \\
(27 / 190)\end{array}$ & $\begin{array}{l}\mathrm{O}_{2} \text { cons.: } \mathrm{n}=8 \\
(54 / 244)\end{array}$ \\
\hline $3.5^{\circ} \mathrm{C}$ & $\begin{array}{l}384 \\
(96 / \operatorname{tank} A 4-D 4) \\
\text { f:m: } 208: 48\end{array}$ & $\begin{array}{l}\mathrm{n}=32 \\
\mathrm{O}_{2} \text { cons.: } \mathrm{n}=8 \\
\text { (1) }\end{array}$ & $\begin{array}{l}\mathrm{n}=32 \\
\mathrm{O}_{2} \text { cons.: } \mathrm{n}=8 \\
(27 / 28)\end{array}$ & $\begin{array}{l}\mathrm{n}=32 \\
(25 / 53)\end{array}$ & $\begin{array}{l}\mathrm{n}=32 \\
(29 / 82)\end{array}$ & $\begin{array}{l}\mathrm{n}=32 \\
(28 / 110)\end{array}$ & $\begin{array}{l}\mathrm{n}=32 \\
(28 / 138)\end{array}$ & $\begin{array}{l}\mathrm{n}=32 \\
(23 / 161)\end{array}$ & $\begin{array}{l}\mathrm{n}=32 \\
(27 / 188)\end{array}$ & $\begin{array}{l}\mathrm{O}_{2} \text { cons.: } \mathrm{n}=8 \\
(56 / 244)\end{array}$ \\
\hline $5.0^{\circ} \mathrm{C}$ & $\begin{array}{l}384 \\
(96 / \operatorname{tank} A 5-D 5) \\
\text { f:m: } 185: 63\end{array}$ & $\begin{array}{l}\mathrm{n}=32 \\
\mathrm{O}_{2} \text { cons.: } \mathrm{n}=8 \\
\text { (1) }\end{array}$ & $\begin{array}{l}\mathrm{n}=32 \\
\mathrm{O}_{2} \text { cons.: } \mathrm{n}=8 \\
(27 / 28)\end{array}$ & $\begin{array}{l}\mathrm{n}=32 \\
(30 / 58)\end{array}$ & $\begin{array}{l}\mathrm{n}=32 \\
(27 / 85)\end{array}$ & $\begin{array}{l}\mathrm{n}=32 \\
(29 / 114)\end{array}$ & $\begin{array}{l}\mathrm{n}=32 \\
(28 / 142)\end{array}$ & $\begin{array}{l}\mathrm{n}=32 \\
(28 / 170)\end{array}$ & $\begin{array}{l}\mathrm{n}=24 \\
(28 / 198)\end{array}$ & $\begin{array}{l}\mathrm{O}_{2} \text { cons.: } \mathrm{n}=8 \\
(46 / 244)\end{array}$ \\
\hline $7.0^{\circ} \mathrm{C}$ & $\begin{array}{l}384 \\
\text { (96/tank A6-D6) } \\
\text { f:m: } 185: 63\end{array}$ & $\begin{array}{l}\mathrm{n}=32 \\
\mathrm{O}_{2} \text { cons.: } \mathrm{n}=8 \\
\text { (1) }\end{array}$ & $\begin{array}{l}\mathrm{n}=32 \\
\mathrm{O}_{2} \text { cons.: } \mathrm{n}=8 \\
(27 / 28)\end{array}$ & $\begin{array}{l}\mathrm{n}=32 \\
(28 / 56)\end{array}$ & $\begin{array}{l}\mathrm{n}=32 \\
(27 / 83)\end{array}$ & $\begin{array}{l}\mathrm{n}=32 \\
(29 / 112)\end{array}$ & $\begin{array}{l}\mathrm{n}=32 \\
(28 / 140)\end{array}$ & $\begin{array}{l}\mathrm{n}=32 \\
(28 / 168)\end{array}$ & $\begin{array}{l}\mathrm{n}=24 \\
(28 / 196)\end{array}$ & $\begin{array}{l}\mathrm{O}_{2} \text { cons.: } \mathrm{n}=8 \\
(48 / 244)\end{array}$ \\
\hline
\end{tabular}


cells $\cdot \mathrm{mL}^{-1}$ ), the chlorophyte Pyramimonas gelidicola (final concentration of $2.2 \times 10^{4}$ cells $\cdot \mathrm{mL}^{-1}$ ) and the cryptophyte Geminigera cryophila (final concentration of $2.0 \times 10^{4}$ cells $\cdot \mathrm{mL}^{-1}$ ). In addition, instant algae were added to yield a final concentration of $1.1 \times 10^{4}$ cells $\mathrm{mL}^{-1}$ Thalassiosira weissfloggii (1200 T M, Reed Mariculture, USA), $5.34 \times 10^{4}$ cells $\mathrm{mL}^{-1}$ Isochrysis sp. (1800 T M, Reed Mariculture, USA) and $5.08 \times 10^{4}$ cells $\mathrm{mL}^{-1}$ Pavlova sp. (1800 T M, Reed Mariculture, USA) per tank. Krill also received $0.625 \mathrm{~g}$ nutritional supplements per tank (0.3125 g of Frippak \#1 CAR and $0.3125 \mathrm{~g}$ of Frippak \#2 CD powder, Primo Aquaculture, Australia). During feeding, water inflow was not turned off to keep water temperature constant. However, the flow rate in the experimental tanks ensured sufficient residence time of food in the water column (full tank water exchange every $\sim 2$ hours). All tanks were checked daily for moults and dead individuals and scraped weekly to prevent biofouling. Within each cluster, mean mortality in experimental tanks A-D [\% $\%$ sd] from September 2017 to April 2018 was $15.10 \pm 2.76 \%\left(0.5{ }^{\circ} \mathrm{C}\right), 13.80$ $\pm 4.76 \%\left(1.5{ }^{\circ} \mathrm{C}\right), 9.38 \pm 2.69 \%\left(2.5{ }^{\circ} \mathrm{C}\right), 12.24 \pm 2.15 \%\left(3.5{ }^{\circ} \mathrm{C}\right)$, $11.46 \pm 5.54 \%\left(5{ }^{\circ} \mathrm{C}\right)$ and $16.41 \pm 2.99 \%\left(7{ }^{\circ} \mathrm{C}\right)$. At each sampling time point $\left(\mathrm{T}_{0}-\mathrm{T}_{7}\right.$; see Table 1$)$, sex, weight, body and carapace length as well as length of the digestive gland of 8 individuals per tank A-D ( $n=32$ per cluster) were measured, except of $\mathrm{T}_{7}$ where 6 individuals per tank A-D (n $=24$ per cluster) were sampled at $5{ }^{\circ} \mathrm{C}$ and $7{ }^{\circ} \mathrm{C}$ due to logistic restrictions. Krill sampling was conducted by using a hand net which was carefully lowered into the tubular tanks (A-D ; per cluster, respectively) to avoid any kind of sampling stress. After accidentally swimming into the net, krill was then carefully transferred to a beaker containing temperate seawater and quickly measured at the respective acclimation temperature. Body length of krill [mm] was measured from the anterior tip of the rostrum to the posterior tip of the uropods, excluding any setae (standard length (standard measurement; S1) (Mauchline, 1980). Mean initial krill length per cluster at $\mathrm{T}_{0}$ was for $0.5{ }^{\circ} \mathrm{C}: 34.66 \mathrm{~mm} 95 \% \mathrm{CI}$ [35.47, 33.84], for $1.5^{\circ} \mathrm{C}: 35.14 \mathrm{~mm} 95 \% \mathrm{CI}$ [35.75, 34.53], for $2.5^{\circ} \mathrm{C}$ : $34.06 \mathrm{~mm} 95 \%$ CI [34.91, 33.21], $3.5{ }^{\circ} \mathrm{C}: 35.60 \mathrm{~mm} 95 \%$ CI [36.37, 34.84], for $5.0{ }^{\circ} \mathrm{C}: 35.35 \mathrm{~mm} 95 \%$ CI $[36.40,34.31]$ and for $7.0{ }^{\circ} \mathrm{C}$ : $34.10 \mathrm{~mm} 95 \%$ CI [34.83, 33.37]. Measurements of carapace length [mm] (anterior tip of rostrum to dorsal end of carapace) and the length of digestive gland (along its diagonal axis) were carried out using a stereomicroscope (Leica M205C, Leica, Germany) with an attached digital camera (Leica DFC450, Leica, Germany). Pictures of the sexual organs (female thelycum and male petasma) were also taken. In this experiment, all individuals were classified as sub-adult males/females (Stage IIA/B, respectively) according to Makarov and Denys (1981). Wet weight [mg] was determined in a beaker filled with temperate seawater on a balance. After weight measurement, each krill was quickly blotted dry, immediately snap frozen in liquid nitrogen and stored at $-80{ }^{\circ} \mathrm{C}$ for further analyses. Handling time was always kept at minimum.

\subsection{Oxygen consumption}

Oxygen consumption ( $\mu$ mol $\mathrm{O}_{2} \mathrm{~g} \mathrm{fwt}^{-1} \mathrm{~h}^{-1}$ ) was measured after 24 hours $\left(\mathrm{T}_{0}\right)$, after one month $\left(\mathrm{T}_{1}\right)$ and after 8 months $\left(\mathrm{T}_{8}\right)$ of incubation (see Table 1). The measurements were conducted at the respective experimental temperature in $2.0 \mathrm{~L}$ Schott bottles (Duran, Germany), equipped with PSt3 oxygen sensor spots (Presens, Regensburg, Germany) and filled with filtered seawater $(0.5 \mu \mathrm{m})$ acclimatized to the respective experimental water temperature (see Table 1). Prior to measurements, two-point calibrations were performed using nitrogen and aeration to calibrate the $0 \%$ and $100 \%$ air saturation points within the medium. Krill was not fed for 24 hours prior to measurements. Before each measurement, sex and wet weight were recorded. After carefully inserting individual krill, each bottle was closed without any air entrapped and lowered back into the water bath. Water baths were installed in a modified fridge to avoid temperature fluctuations due to changes in air temperature. Each water bath within the fridge was equipped with a controller unit regulating individual heating rods to control water bath temperatures. To ensure sufficient mixing, each
Table 2

Results of linear mixed effects model analysis for a) oxygen consumption [ $\mu \mathrm{mol} g$ $\mathrm{fwt}^{-1} \mathrm{~h}^{-1}$ ], b) body length [mm] and c) digestive gland length [\% body length].

\begin{tabular}{|c|c|c|c|c|}
\hline \multicolumn{2}{|c|}{ a) Oxygen consumption $\left[\mu \mathrm{mol} g f w t^{-1} h^{-1}\right]$} & \multirow{2}{*}{\multicolumn{3}{|c|}{$\begin{array}{l}\text { Linear mixed-effects model fit by } \\
\text { REML } \\
\text { adj. } R^{2}: 0.574\end{array}$}} \\
\hline & & & & \\
\hline \multicolumn{2}{|l|}{ Fixed effects } & numDF & F & $p$ \\
\hline \multirow{2}{*}{\multicolumn{2}{|c|}{$\begin{array}{l}\text { (Intercept) } \\
\text { ftime }\end{array}$}} & 1 & 2887.02 & $<0.0001$ \\
\hline & & 2 & 12.50 & $<0.0001$ \\
\hline \multicolumn{2}{|l|}{ ftreat } & 5 & 27.74 & $<0.0001$ \\
\hline \multicolumn{2}{|l|}{ ftime:ftreat } & 10 & 3.18 & 0.0011 \\
\hline \multicolumn{5}{|l|}{ Random effects } \\
\hline \multicolumn{2}{|l|}{ StdDev. } & (Intercept) & Residual & \\
\hline StdDev. & & 0.000022 & 0.67 & \\
\hline \multirow[t]{2}{*}{ b) Body length $[\mathrm{mm}]$} & \multicolumn{4}{|c|}{ Linear mixed-effects model fit by REML } \\
\hline & \multicolumn{4}{|c|}{ adj. $R^{2}: 0.460$} \\
\hline Fixed effects & numDF & \multicolumn{2}{|c|}{ F } & $p$ \\
\hline (Intercept) & 1 & \multirow{2}{*}{\multicolumn{2}{|c|}{410303.91}} & $<0.0001$ \\
\hline ftime & 7 & \multirow{2}{*}{\multicolumn{2}{|c|}{$\begin{array}{l}102.04 \\
56.42\end{array}$}} & $<0.0001$ \\
\hline ftreat & 5 & & & $<0.0001$ \\
\hline fsex & 1 & \multicolumn{2}{|c|}{5.846} & 0.0157 \\
\hline ftime:ftreat & 35 & \multicolumn{2}{|c|}{6.466} & $<0.0001$ \\
\hline ftime:fsex & 7 & \multicolumn{2}{|c|}{9.187} & $<0.0001$ \\
\hline
\end{tabular}

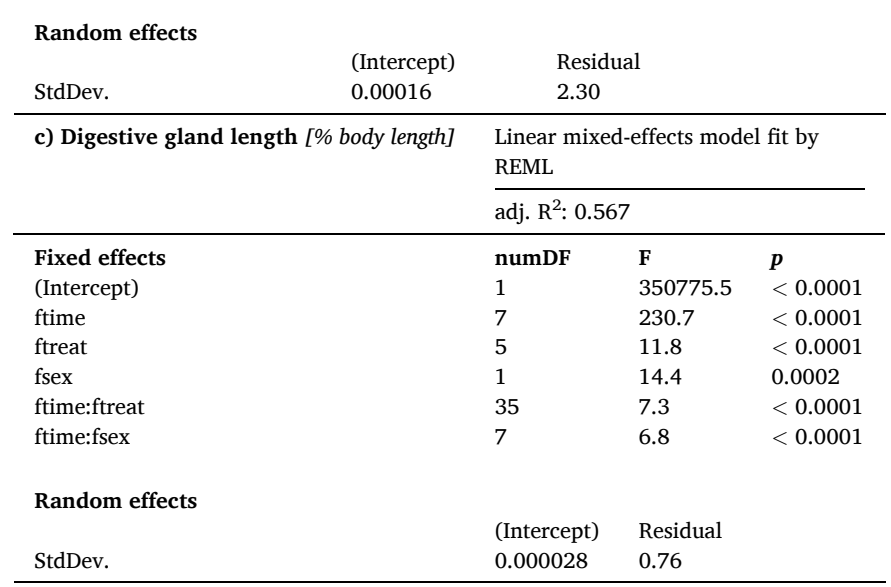

water bath was additionally equipped with an individual pump. The light regime within the fridge was identical to the holding system (see above), using an additional light system installed at the back of the fridge. Oxygen concentrations within the bottles were measured for $\sim 24$ hours, using an OXY 10-Channel Oxygen Meter (Presens, Regensburg, Germany). Two bottles served as controls to account for bacterial respiration. After each measurement, krill was snap frozen and stored at $-80^{\circ} \mathrm{C}$. The decrease in oxygen concentrations within all bottles was $\leq$ $12 \%$ of the initial concentration.

The decrease in oxygen concentration over time within each bottle was analyzed using linear regression analysis. To exclude any possible stress response to handling, only data recorded later than $1 \mathrm{~h}$ after start of the measurement were used. Mean $\mathrm{R}^{2} \pm \mathrm{sd}$ across all channels and treatments was for $\mathrm{T}_{0}: 0.95 \pm 0.06$, for $\mathrm{T}_{1}: 0.91 \pm 0.12$ and for $\mathrm{T}_{8}: 0.93 \pm$ 0.11 , respectively. Values are given in micromole oxygen per gram fresh weight per hour [ $\mu \mathrm{mol} \mathrm{g} \mathrm{fwt}^{-1} \mathrm{~h}^{-1}$ ].

\subsection{Statistics}

Data analysis was performed in RStudio version 1.3.959 (RStudio Team, 2020) using R version 4.0.1 (R Core Team, 2020). Data sets were visually checked before analysis using scatterplots. One data point was removed from the data set of body length $[\mathrm{mm}]$ and digestive gland length [\% body length]) due to an obvious data entry error. For the dependent variable oxygen consumption rate $\left[\mu \mathrm{mol} \mathrm{g} \mathrm{fwt} \mathrm{t}^{-1} \mathrm{~h}^{-1}\right]$, two 

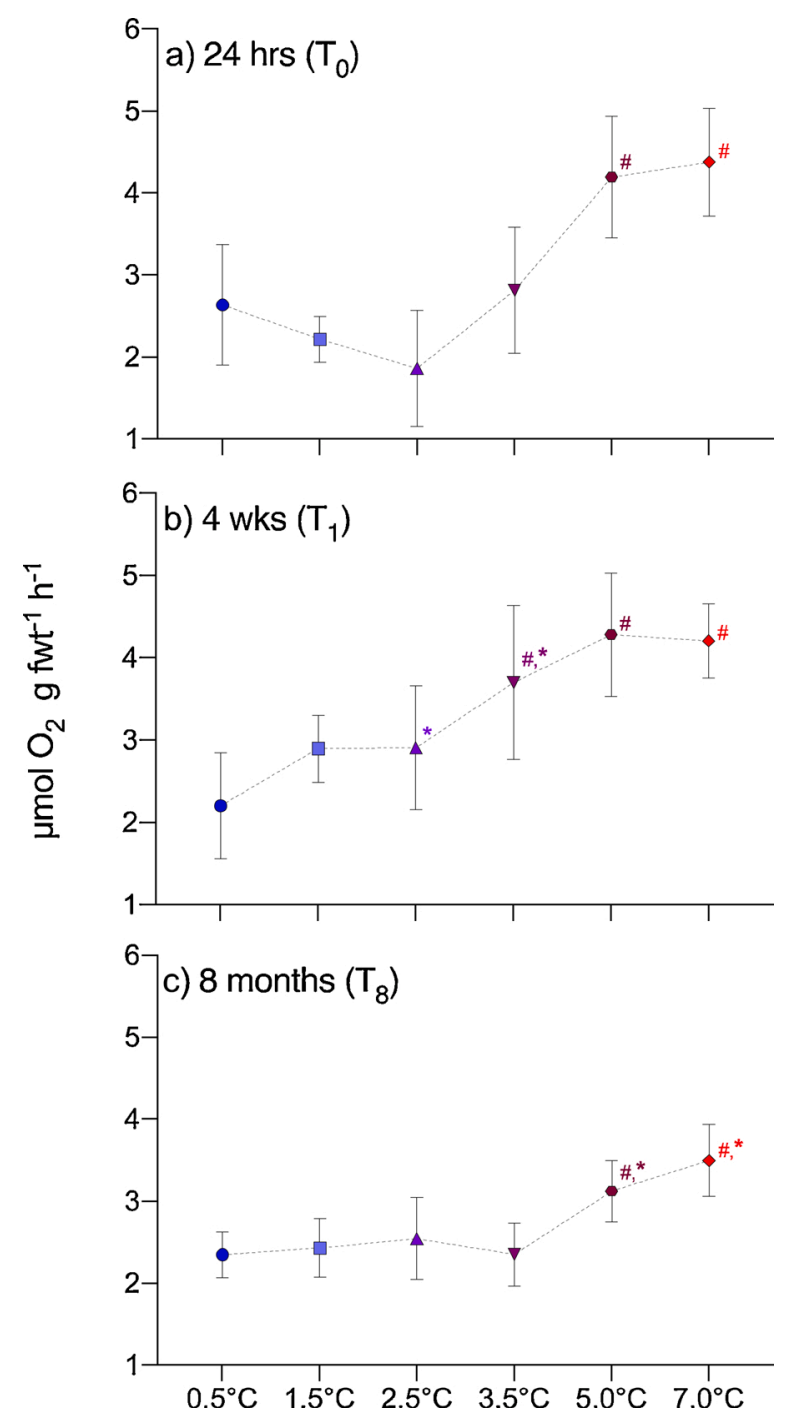

Fig. 1. Oxygen $\left(\mathrm{O}_{2}\right)$ consumption rates $\left[\mu \mathrm{mol} \mathrm{g} \mathrm{fwt} \mathrm{fw}^{-1} \mathrm{~h}^{-1}\right] \pm 95 \% \mathrm{CI}$ of Antarctic krill (E. superba) after a) 24 hours $\left(\mathrm{T}_{0}\right)$, b) 4 weeks $\left(\mathrm{T}_{1}\right)$ and, c) 8 months $\left(\mathrm{T}_{8}\right)$ of acclimation at different experimental temperatures (cluster 1-6) in the laboratory. At each timepoint, $\mathrm{O}_{2}$ consumption was measured for $\sim 24$ hours at the respective experimental temperature. Significant differences compared to control temperature $\left(0.5^{\circ} \mathrm{C}\right)$ within timepoints are indicated by hash tags; significant differences compared to $\mathrm{T}_{0}$ within each temperature treatment by asterisks. $\mathrm{p} \leq 0.05$ (Dunnett's test). $\mathrm{n}=7-8$ per experimental temperature and timepoint, except of cluster 1 at $T_{8}(n=15)$; see also Table 1 .

replicates were removed from the data set before analysis due to the death of experimental krill during measurements at $\mathrm{T}_{0}\left(\mathrm{n}=1\left(2.5^{\circ} \mathrm{C}\right) ; \mathrm{n}\right.$ $=1\left(3.5^{\circ} \mathrm{C}\right)$ ). Applying the $99 \%$ quantile method for the remaining data, four outliers were detected and subsequently removed from the data set (T0: $\mathrm{n}=1\left(5^{\circ} \mathrm{C}\right) ; \mathrm{T} 1: \mathrm{n}=2\left(3.5^{\circ} \mathrm{C}\right.$ and $\left.5^{\circ} \mathrm{C}\right) ; \mathrm{T} 8: \mathrm{n}=1\left(0.5^{\circ} \mathrm{C}\right)$. Dependent variables (oxygen consumption rate $\left[\mu \mathrm{mol} \mathrm{g} \mathrm{fwt} \mathrm{f}^{-1} \mathrm{~h}^{-1}\right.$, body length $[\mathrm{mm}]$ and digestive gland length [\% body length]) were visually checked for normal distribution using histograms. To investigate the effects of experimental temperature (factor treatment; ftreat) and the variation over time (factor time; ftime) on dependent variables, linear mixed models with a Gaussian distribution were fitted using the nlme package in R (Pinheiro et al., 2020). In addition, the factor sex (fsex) was considered to account for variations between sexes. A random term for experimental tank (A-D, see Table 1) was included to account for a potential tank effect. The best combination of explanatory variables, including interactions, was found by step-wise forward model selection. A term was added to the model when it resulted in an increase in $R^{2}$, a

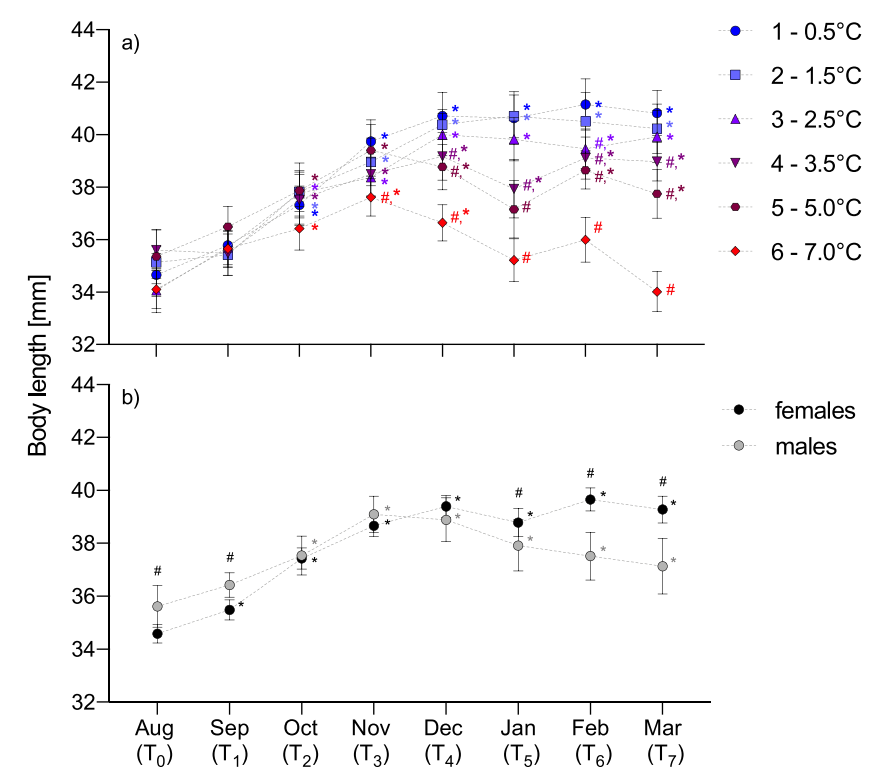

Fig. 2. Body length [mm] $\pm 95 \%$ CI of Antarctic krill (E. superba) during 7 months of acclimation at (a) different experimental temperatures (cluster 1-6; see figure legend) in the laboratory and (b) of female (black) and male (grey) Antarctic krill, averaged over the different levels of the factor temperature. (a) Significant differences compared to control temperature $(0.5$ ${ }^{\circ} \mathrm{C}$ ) within timepoints are indicated by hash tags; significant differences compared to $\mathrm{T}_{0}$ within each temperature treatment by asterisks. (b) Significant differences between sexes within timepoints are indicated by hash tags; significant differences compared to $\mathrm{T}_{0}$ within females/males by asterisks. $\mathrm{p} \leq 0.05$ (Dunnett's test). $\mathrm{n}=24-32$ per experimental temperature and timepoint, respectively (see Table 1 ).

decrease in akaike information criterion (AIC) and when it was significant at the $\alpha=0.05$ level. Validation of the final model was examined by residual analysis, including testing for temporal auto-correlation (using the acf function). See Table 2 for model results as well as supplementary material for mean values of the respective parameters (Table S.1-3/S.5-6). Multiple comparison posthoc tests (Dunnett's test) were performed to detect significant differences compared to the respective controls of the factor temperature (ftreat; $0.5^{\circ} \mathrm{C}$ ) and factor time (ftime; $\mathrm{T}_{0}$ ).

\section{Results}

\subsection{Oxygen consumption rates}

Temperature effects on routine metabolic rates (determined by oxygen consumption rates) of Antarctic krill (E. superba) varied significantly with time $\left(\mathrm{T}_{0}, \mathrm{~T}_{1}\right.$ and $\mathrm{T}_{8} ; \mathrm{p}=0.001$ ) (Fig. 1 ; see also Table 2 for model results). After 24 hours of incubation at the respective acclimation temperatures, oxygen consumption was higher in krill acclimated to $5{ }^{\circ} \mathrm{C}(\mathrm{p} \leq 0.001)$ and $7{ }^{\circ} \mathrm{C}(\mathrm{p} \leq 0.001)$ compared to krill acclimated to control temperature. After 4 weeks of acclimation $\left(\mathrm{T}_{1}\right)$, oxygen consumption of krill acclimated to water temperatures $\geq 3.5^{\circ} \mathrm{C}$ was significantly higher compared to control conditions ( $\mathrm{p} \leq 0.001$, respectively). Krill acclimated to $2.5^{\circ} \mathrm{C}$ and $3.5^{\circ} \mathrm{C}$ also showed a significant increase in oxygen consumption compared to $\mathrm{T}_{0}(\mathrm{p}=0.0064$ and $\mathrm{p}=0.029$, respectively). However, after 8 months, oxygen consumption of krill acclimated to $2.5{ }^{\circ} \mathrm{C}$ and $3.5{ }^{\circ} \mathrm{C}$ returned back to control $\left(0.5^{\circ} \mathrm{C}\right)$ levels. Again, significantly higher values compared to the control could be detected in krill acclimated to $5{ }^{\circ} \mathrm{C}(\mathrm{p}=0.040)$ and $7{ }^{\circ} \mathrm{C}(\mathrm{p} \leq 0.001)$. Compared to $\mathrm{T}_{0}$ (24 hours), oxygen consumption of krill acclimated to $5^{\circ} \mathrm{C}$ and $7{ }^{\circ} \mathrm{C}$ was significantly lower $\left(5^{\circ} \mathrm{C}: \mathrm{p}=0.005\right.$; $\left.7^{\circ} \mathrm{C}: \mathrm{p}=0.019\right)$ after 8 months $\left(\mathrm{T}_{8}\right)$. 


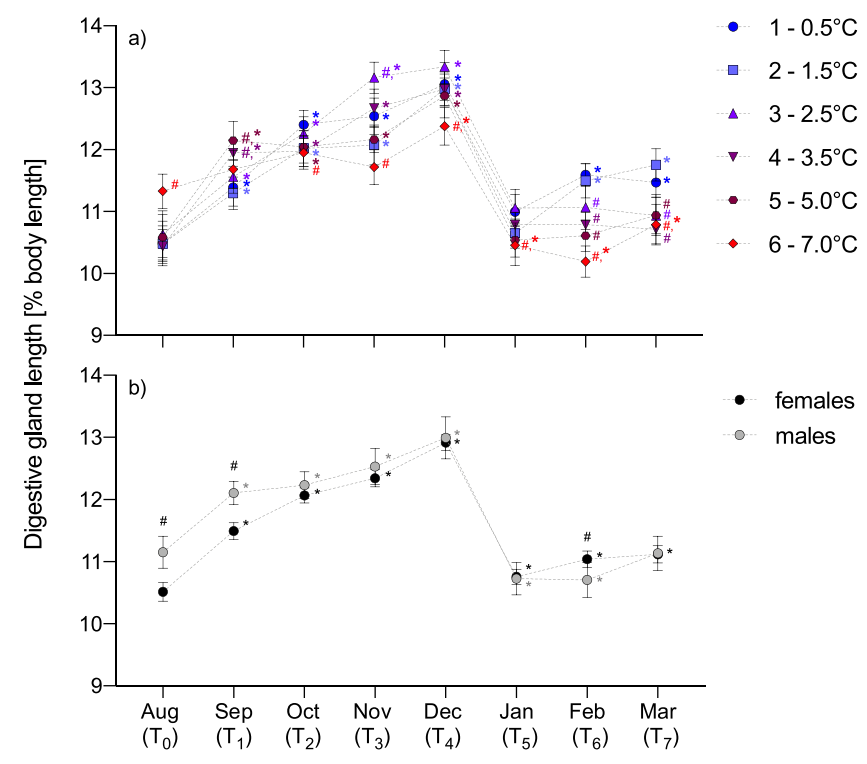

Fig. 3. Digestive gland (DG) length [\% body length] $\pm 95 \%$ CI of Antarctic krill (E. superba) during 7 months of acclimation (a) at different experimental temperatures (cluster 1-6; see figure legend) in the laboratory and (b) of female (black) and male (grey) Antarctic krill, averaged over the different levels of the factor temperature. (a) Significant differences compared to control temperature $\left(0.5^{\circ} \mathrm{C}\right)$ within timepoints are indicated by hash tags; significant differences compared to $\mathrm{T}_{0}$ within each temperature treatment by asterisks. (b) Significant differences between sexes within timepoints are indicated by hash tags; significant differences compared to $\mathrm{T}_{0}$ within females/males by asterisks. $\mathrm{p} \leq 0.05$ (Dunnett's test). $\mathrm{n}=24-32$ per experimental temperature and timepoint, respectively (see Table 1).

\subsection{Morphometric parameters}

\subsubsection{Body length}

Krill growth in length was assessed indirectly by comparing changes in mean body length [mm] over time. The effects of the different experimental temperatures on krill growth in length varied significantly with time ( $\mathrm{p}<0.001$; see also Table 2). From August till December, a significant increase in body length could be detected in all treatments (Fig. 2a). No significant differences to the control $\left(0.5{ }^{\circ} \mathrm{C}\right)$ could be observed, except for krill acclimated to $7{ }^{\circ} \mathrm{C}$ from November onwards ( $\mathrm{p}$ $<0.01$ ). Thereafter, the magnitude of growth over time was inversely correlated with experimental temperature: In krill acclimated to temperatures $\leq 2.5^{\circ} \mathrm{C}$, no effect of acclimation temperatures was evident. Body lengths steadily increased until December with only small increases in length thereafter. At the end of the experiment (March, $\mathrm{T}_{7}$ ), body lengths of krill acclimated to temperatures $\leq 2.5{ }^{\circ} \mathrm{C}$ were significantly higher compared to the start of the experiment in August. In contrast, krill acclimated to temperatures $\geq 3.5{ }^{\circ} \mathrm{C}$ grew significantly less from December onwards. This general pattern remained until the end of the experiment in March, resulting in shorter lengths compared to control animals at all experimental temperatures $\geq 3.5^{\circ} \mathrm{C}$. Krill acclimated to $3.5^{\circ} \mathrm{C}$ and $5{ }^{\circ} \mathrm{C}$ still grew from December onwards but at lower rates, resulting in smaller length increments during the whole experimental phase $\left(3.5^{\circ} \mathrm{C}\right.$ : $9.5 \%$ and $5{ }^{\circ} \mathrm{C}: 6.8 \%$ of initial body length at $\left.\mathrm{T}_{0}\right)$. Body lengths of krill acclimated to $7{ }^{\circ} \mathrm{C}$ profoundly decreased over time after December. Consequently, krill were smaller compared to their initial starting length $(-0.2 \%)$ as well as compared to krill acclimated to control conditions $(-16.7 \% ; \mathrm{p}<0.001)$ at the end of the experiment.

Independent of experimental temperatures, krill growth over time also varied significantly with sex ( $<<0.001$; Table 2) (Fig. 2b). Body lengths of both, males and females increased from August $\left(\mathrm{T}_{0}\right)$ till December $\left(\mathrm{T}_{4}\right)$. No notable difference in body length could be detected for both sexes within that period, although lengths in males were slightly higher during the initial phase of the experiment (August - September; $\mathrm{p}$ $<0.05$, respectively). Thereafter, length increments decreased in males (i.e. shrinking) and steadied in females, resulting in significantly higher values for females compared to males from January onwards. At the end of the experiment, the increase in body length of male krill was smaller (4.3\%; $\mathrm{p}<0.05)$ compared to that of female krill $(13.5 \%$; $<0.001)$ over time.

\subsubsection{Digestive gland (DG) length [\% body length]}

The effects of acclimation temperature on the size of the digestive gland (DG) in percent body length [\%] varied notably with time ( $\mathrm{p}<$ 0.001; see also Table 2) (Fig. 3a). From August till December, a significant increase in DG size could be detected in all treatments (Fig. 3a). Within this time period, no significant differences to the control $\left(0.5^{\circ} \mathrm{C}\right)$ could be observed, except of krill acclimated to $7^{\circ} \mathrm{C}$, where differences already began to emerge from October onwards and significantly higher DG sizes of krill acclimated at $3.5^{\circ} \mathrm{C}$ and $5.0{ }^{\circ} \mathrm{C}$ in September $\left(\mathrm{T}_{1}\right)$ only. After reaching peak values in December $\left(\mathrm{T}_{4}\right)$, DG size decreased again and steadied thereafter until the end of the experiment in March. However, at experimental temperatures $<2.5^{\circ} \mathrm{C}$ a trend to increasing values became visible from January to March, which could not be observed in temperature treatments $\geq 2.5^{\circ} \mathrm{C}$. DG size of krill acclimated to temperatures $\geq 2.5^{\circ} \mathrm{C}$ remained below control values from January (7 $\left.{ }^{\circ} \mathrm{C}\right) /$ February $\left(2.5^{\circ} \mathrm{C}-5^{\circ} \mathrm{C}\right)$ onwards.

Patterns of DG size change over time also varied significantly with sex, independent of acclimation temperature $(\mathrm{p}<0.001$; see also Table 2). The DG of both sexes significantly increased from August $\left(\mathrm{T}_{0}\right)$ till December $\left(\mathrm{T}_{4}\right)$ (Fig. 3b) with higher initial values in males during the first two months of incubation $\left(\mathrm{T}_{0}\right.$ : $\mathrm{p}<0.001 ; \mathrm{T}_{1}$ : $\left.\mathrm{p}<0.001\right)$. After reaching peak values in December, DG size decreased in both sexes and remained unchanged for the rest of the experimental period. At the end of the experiment in March, the DG of female krill was significantly larger than at the start of the experiment in August (5.8\%; $<<0.001)$, whereas the DG in males returned to its initial size $(-0.15 \% ; \mathrm{p}=1.00)$.

\section{Discussion}

Antarctic krill experience high regional differences in habitat temperatures due to its horizontal and vertical distribution and the full natural temperature range of krill was suggested to lie between -1.8 and $5.5{ }^{\circ} \mathrm{C}$ (Tarling, 2020). Future scenarios predict ongoing changes, although regional impacts may vary (Meredith et al., 2019). In order to understand the effects of rising water temperatures in the Southern Ocean on Antarctic krill, a thorough understanding of its' physiological responses to temperature is urgently needed (Meyer and Teschke, 2016). We therefore captured the whole animal performance of Antarctic krill by investigating oxygen consumption rates, changes in mean body length as well as length of the digestive gland at different experimental temperatures.

\subsection{Temperature effects on krill oxygen consumption}

Oxygen consumption rate is a good measure of physiological performance and capacity (Buchholz, 2003) and used as a proxy for metabolic rate (Tarling, 2020). To date, studies on krill respiration mostly comprised acute and short-term experiments with short acclimation times (from hours to a few days) (McWhinnie and Marciniak, 1964; Rakusa-Suszczewski and Opalinski, 1978; Segawa et al., 1979; Hirche, 1984; Opalinski, 1991; Ngan et al., 1997; Tarling, 2020). Here, acute ( 24 hours), short- (4 weeks) as well as long-term responses ( 8 months) were measured.

Although a high variability in the acute measurements (24 hours; Fig. 1a) was observed, oxygen consumption of krill remained unchanged at temperatures $\leq 3.5^{\circ} \mathrm{C}$ under both, acute ( 24 hours) and long-term ( 8 months) conditions (Fig. 1a and c). This may indicate a compensated thermal range in Antarctic krill (here: $0.5^{\circ} \mathrm{C}$ to $3.5^{\circ} \mathrm{C}$ ), where oxygen 
consumption remains largely independent of temperature. Indeed, previous studies found krill oxygen consumption to be temperatureindependent within different thermal ranges of their natural environment (e.g. McWhinnie and Marciniak, 1964; Segawa et al., 1979; Ngan et al., 1997). Accordingly, Brown et al. (2013) could not detect significant effects of acclimation temperature $\left(-1{ }^{\circ} \mathrm{C}, 1{ }^{\circ} \mathrm{C}\right.$ and $3{ }^{\circ} \mathrm{C}$, respectively) on oxygen consumption rates under long-term conditions (March - May). These results were suggested to be a strategy to deal with changes in water temperature during diel vertical migration (Opalinski, 1991). However, a different pattern was observed under short-term (4 weeks) conditions (Fig. 1b), where oxygen consumption was significantly higher at temperatures $>2.5{ }^{\circ} \mathrm{C}$ and also showed an increasing trend with increasing experimental temperature, in line with findings of Hirche (1984) and Tarling (2020). The different patterns observed in the response of krill oxygen consumption rates to temperature were previously suggested to be related to the employment of different methods, animals from different regions as well as different experimental designs (Ngan et al., 1997). Due to the relatively low number of replicates per temperature and timepoint, respectively, an underlying trend of increasing respiration rates may have remained unresolved under acute (24 hours) and long-term (8 months) conditions, leading to the different patterns observed compared to short-term conditions (4 weeks). The time dependency of different acclimation processes at the lower end of the studied temperature range may also have contributed to the different patterns observed. Specifically, a higher variance is visible in measurements under acute and short-term compared to long-term conditions. Clearly, further studies, involving a higher number of replicates as well as more comparable, stringent methodological approaches with respect to (pre-) acclimation times, are needed for Antarctic krill.

At high acclimation temperatures $\left(5^{\circ} \mathrm{C}\right.$ and $\left.7{ }^{\circ} \mathrm{C}\right)$, significantly higher metabolic rates were detected under acute ( 24 hours) and shortterm (4 weeks) conditions with no further increase at acclimation temperatures $>5{ }^{\circ} \mathrm{C}$ (Fig. $1 \mathrm{a}$ and b). No further increase in oxygen consumption at water temperatures higher than $5.5^{\circ} \mathrm{C}$ was also detected by Tarling (2020) under acute conditions. In contrast, no such leveling-off of oxygen consumption rates at experimental temperatures $>5{ }^{\circ} \mathrm{C}$ was observed by Hirche (1984) and Opalinski (1991). Nevertheless, krill are considered to be stenothermal. Even though they can tolerate short-term temperature increases $\geq 10{ }^{\circ} \mathrm{C}$ to a certain degree (McWhinnie and Marciniak, 1964; Cascella et al., 2015; Tarling, 2020), thermal thresholds are expected to arise at constant, high water temperatures as applied here $\left(\geq 5^{\circ} \mathrm{C}\right)$. An upper thermal threshold at temperatures of $\sim$ $5{ }^{\circ} \mathrm{C}$ was previously suggested for Antarctic krill under acute and short-term conditions (Clarke and Morris, 1983; Tarling, 2020). After 8 months of acclimation, krill were able to compensate for the effects of temperature at $5{ }^{\circ} \mathrm{C}$ and $7{ }^{\circ} \mathrm{C}$, although compensation remained incomplete and oxygen consumption rates were still significantly higher compared to the control value $\left(0.5^{\circ} \mathrm{C}\right)$ (Fig. 1c). Therefore, although our findings suggest that krill may be able to adjust routine metabolic rates at higher temperatures to a certain degree over time, metabolic rates remain elevated at temperatures $\geq 5{ }^{\circ} \mathrm{C}$, even after long-term acclimation. Once again this emphasizes temporal differences in the response of krill oxygen consumption to changes in water temperatures (see above).

Together, our findings indicate that warming Southern Ocean waters are likely to increase routine metabolic rates in krill at temperatures $>$ $3.5^{\circ} \mathrm{C}$. This is possibly altering the amount of energy available for other important life-cycle processes such as growth and/or reproduction (Pörtner, 2010; Sokolova, 2013). Despite temporal differences observed between the different experimental timepoints, oxygen consumption rates remained unchanged up to $3.5{ }^{\circ} \mathrm{C}$ under long-term conditions. If this finding represents a strategy to deal with natural temperature oscillations during vertical movements in the water column remains to be investigated. Furthermore, underlying processes and potential energetic trade-offs need further investigation. Local differences in thermal habitats may also alter the capacities to acclimate to changing water temperatures in the future and thus, additionally modify effect sizes across the distribution range of Antarctic krill (Tarling, 2020).

\subsection{Temperature effects on krill growth}

Somatic growth is a good indicator for the response of an animal to the environment since it is the sum of a number of major physiological processes (Tarling et al., 2006). In krill, growth has already been investigated in numerous laboratory and field studies, extensively reviewed by Reiss (2016). Krill growth undergoes a seasonal cycle which was found to be dependent on temperature as well as food quality and quantity (e.g. Poleck and Denys, 1982; Atkinson et al., 2006; Kawaguchi et al., 2006, 2007a; Wiedenmann et al., 2008; Brown et al., 2010). Generally, the annual growth cycle of krill comprises a phase of rapid growth during spring and summer and a phase of little growth in winter, with an overall decrease in the annual increment as reproduction becomes a priority (Constable and Kawaguchi, 2018). Mean initial body length of krill in our experiment was $\sim 35 \mathrm{~mm}$ at $\mathrm{T}_{0}$ (Fig. 2a). Krill mean body lengths $[\mathrm{mm}]$ increased until December and steadied thereafter (Fig. 2a). From August - December, mean daily growth rates (derived from Fig. 2a; normalized to the number of experimental days between samplings, see Table 1$)$ were $0.053 \mathrm{~mm}^{-1 a y}{ }^{-1}\left(0.5^{\circ} \mathrm{C}\right), 0.047 \mathrm{~mm}_{\text {day }}{ }^{-1}$ $\left(1.5{ }^{\circ} \mathrm{C}\right)$ and $0.054 \mathrm{~mm}$ day $^{-1}\left(2.5{ }^{\circ} \mathrm{C}\right)$. From December onwards (December-March), only small positive growth rates could be observed in krill acclimated to temperatures $\leq 2.5^{\circ} \mathrm{C}\left(0.010 \mathrm{~mm} \mathrm{day}^{-1}\right.$ at $0.5^{\circ} \mathrm{C}$, $0.010 \mathrm{~mm} \mathrm{day}^{-1}$ at $1.5^{\circ} \mathrm{C}, 0.013 \mathrm{~mm} \mathrm{day}^{-1}$ at $2.5^{\circ} \mathrm{C}$ ). In the field, growth rates of similar sized krill $(30-40 \mathrm{~mm})$ were $\sim 0.02-0.3 \mathrm{~mm}^{\text {day }}{ }^{-1}$ in January/February (Atkinson et al., 2006), in line with growth rates reported by Kawaguchi et al. (2006) for $40 \mathrm{~mm}$ krill in December. Average growth rates of adult krill also ranged between 0.020 and $0.103 \mathrm{~mm}$ day $^{-1}$ in the early productive season (October to December) (Tarling et al., 2016). Growth rates observed in our experiment are rather at the lower end of the ranges reported from the field but in line with a previous long-term laboratory experiment, reporting mean daily growth rates of $0.03 \mathrm{~mm} \mathrm{day}^{-1}$ at $-1{ }^{\circ} \mathrm{C}$ and $1{ }^{\circ} \mathrm{C}$ and $0.02 \mathrm{~mm} \mathrm{day}^{-1}$ at $3^{\circ} \mathrm{C}$ water temperature during the growth period (August - December) (Brown et al., 2010). A general "lab effect" on growth rates was already proposed earlier, possibly due to sub-optimal laboratory conditions (Buchholz, 1991; Brown et al., 2010). However, as overall growth during the whole experimental phase here was significantly positive at temperatures $\leq 2.5^{\circ} \mathrm{C}$ (Fig. 2a), we can conclude that the experimental conditions generally allowed for positive growth.

In previous field and laboratory studies, the optimum temperature for growth in krill was suggested to lie within the range of $0.5^{\circ} \mathrm{C}$ and 1 ${ }^{\circ} \mathrm{C}$ and that krill growth rates generally decline at temperatures between $3{ }^{\circ} \mathrm{C}$ and $4{ }^{\circ} \mathrm{C}$ (Atkinson et al., 2006; Brown et al., 2010). In our study, significant differences in body lengths of krill acclimated to $\geq 3.5^{\circ} \mathrm{C}$ began to emerge from November $\left(7^{\circ} \mathrm{C}\right)$ and December $\left(3.5^{\circ} \mathrm{C}\right.$ and $\left.5^{\circ} \mathrm{C}\right)$ onwards (Fig. 2a). Although krill still showed positive growth, the magnitude of increments in mean body length declined with increasing acclimation temperatures and, when compared to $\mathrm{T}_{0}$, even led to smaller mean body lengths in krill acclimated to the highest temperature by the end of the experiment $\left(7^{\circ} \mathrm{C}\right.$, Fig. 2a). Therefore, krill acclimated to temperatures $\geq 3.5^{\circ} \mathrm{C}$ were significantly smaller (and lighter; a trend visible in mean fresh weight [mg]; see supplementary material S.4) compared to control conditions at the end of the experiment. Even more important, as the magnitude of the effect of temperature on krill growth depends on the initial size of krill, a possibly even stronger effect on larger krill than those used in our experiment $\left(\sim 35 \mathrm{~mm}\right.$ at $\left.\mathrm{T}_{0}\right)$ may be anticipated (Constable and Kawaguchi, 2018).

Food availability and quality were suggested to have a positive influence on growth rates under suboptimal temperatures (Wiedenmann et al., 2008; Hill et al., 2013; Constable and Kawaguchi, 2018). The size of the digestive gland can serve as a measure of feeding activities during the previous days and weeks but it is also used as an indicator for short-term lipid dynamics during starvation experiments and between seasons (e.g. summer vs. winter) (Virtue et al., 1993; Nicol et al., 2004; 
Teschke et al., 2007). In our study, the daily feeding regime was two hours of intensive feeding (see also 2.2), followed by a period of very limited access to food every day. A marked decline in DG size coinciding with lower mean body length increments was observed at all acclimation temperatures from December onwards (Figs. $2 \mathrm{a}$ and 3 a), a time at which krill are thought to have entered the energy demanding reproductive period. As krill were only able to intensively feed for two hours a day, the feeding regime in our experiment may therefore have become insufficient during this period of high energy demand (i.e. reproductive phase). Therefore, any energy shortage during this period may have been compensated by a diversion of energy from the digestive gland and possibly, also from somatic growth. Reproduction period ends short if food conditions are not sufficient and from February onwards, krill then start to regress their maturity (in other words: enter autumn state) (Kawaguchi, 2016). However, differences in DG size in relation to acclimation temperatures were also observed (Fig. 3a). During the high-growth season (August - December; see above), the size of the digestive gland [\%] was significantly smaller in krill acclimated to $7{ }^{\circ} \mathrm{C}$. Despite the overall decrease in DG size at all acclimation temperatures from December to January, DG size increased again in krill acclimated at temperatures $<2.5^{\circ} \mathrm{C}$ from February onwards, whereas size increments of krill acclimated to temperatures $\geq 2.5^{\circ} \mathrm{C}$ remained low and significantly below control values (Fig. 3a). At higher water temperatures, the changes in energetic requirements within the reproductive phase may therefore have been amplified, also emphasized by the patterns observed in krill acclimated at the highest experimental temperature $(7$ ${ }^{\circ} \mathrm{C}$ ). An effect of temperature on feeding activities itself may serve as a possible explanation for the observed differences in DG size as well as in growth in response to experimental temperature, especially pronounced after the onset of the reproductive period. However, the direct effect of increased temperature on krill feeding rates has not yet been measured (Schmidt and Atkinson, 2016). Also, if the role of the digestive gland in Antarctic krill is the same as in other crustaceans (major site of (short-term) lipid storage and synthesis) (Virtue et al., 1993), the observed effects may also indicate an increasingly lower capacity to feed at a proportional rate and/or to build up the short-term reserves within the digestive gland as temperature increases.

\subsection{Sex-specific differences in krill growth trajectories}

Seasonal differences between male and female growth throughout the summer season (January to March) could be detected (Fig. 2b), whereas no sex-specific differences could be detected in response to different acclimation temperatures. From January onwards, growth in female krill was steadying whereas negative growth could be observed in males (Fig. 2b). Sex-specific differences between seasonal growth rates and/or patterns already observed in previous studies, were suggested to be related to the different energetic requirements for male versus female reproduction and/or dimorphism in growth between sexes (Nicol et al., 1995; Brown et al., 2010; Tarling et al., 2016; Constable and Kawaguchi, 2018; Melvin et al., 2018). In addition, Melvin et al. (2018) only recently introduced a method to obtain sex-specific growth rates by incorporating the length of the carapace into instantaneous growth rate (IGR) measurements. Comparing the traditional method with the new method, they found significant differences between growth rate methods, resulting in higher growth percentages for gravid females using the new (sex-specific) growth rate (IGR) measurement (Melvin et al., 2018). Therefore, the patterns observed here may be related to the seasonal maturity cycle of krill. In our experiment, individuals were classified as late-subadults, as secondary sexual characteristics as well as a progression of maturity over time could be observed (Makarov and Denys, 1981; Kawaguchi, 2016). Establishing a clear relationship between the maturity cycle and the patterns observed here is therefore rather speculative. However, the previous findings together with the sex-specific differences in growth observed here underline the need to include the interaction between reproduction and growth into future life

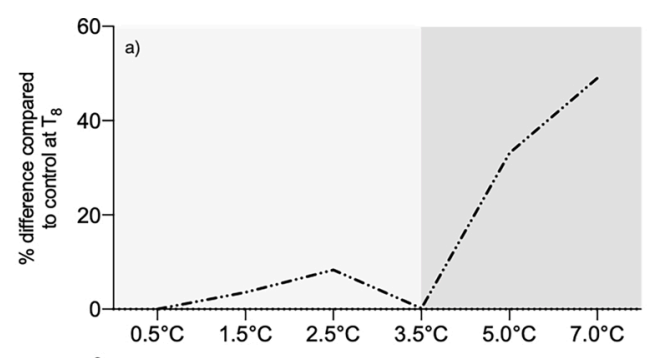

$-\cdots \mathrm{O}_{2}$ consumption

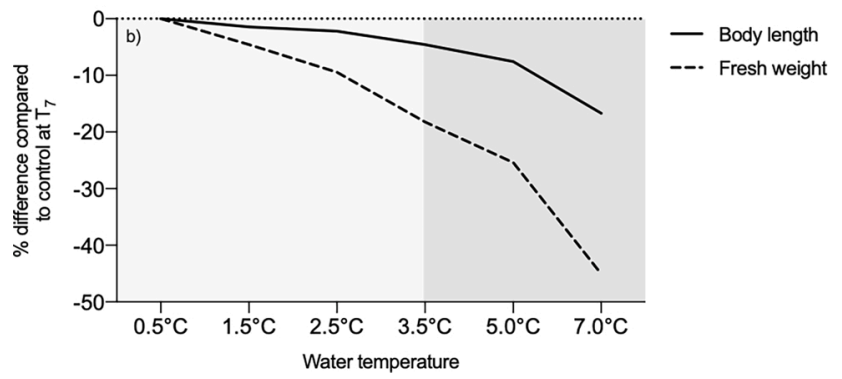

Fig. 4. Schematic overview on percent difference in oxygen consumption, body length and fresh weight compared to control conditions $\left(0.5^{\circ} \mathrm{C}\right)$ after long-term acclimation at different temperatures in the laboratory. a) Percent difference in oxygen consumption compared to control conditions $(0.5$ ${ }^{\circ} \mathrm{C}$ ) after 8 months of acclimation (August-April). b) Percent difference in body length and fresh weight (see supplementary material) compared to control conditions $\left(0.5^{\circ} \mathrm{C}\right)$ after 7 months of acclimation (August-March). See paragraphs 2.2, 2.3 and Table 1 for details on the experimental design. Different shading indicates putative thresholds for the respective parameters.

cycle and population dynamic models, particularly those used in fisheries management, to provide realistic outputs related to sex-specific growth rates and energetics (Tarling et al., 2016; Constable and Kawaguchi, 2018; Melvin et al., 2018). Especially in light of future changes in water temperatures it may reduce data variability and allow for more accurate determination of effect sizes in a warming Southern Ocean.

\subsection{Implications and future perspectives}

Krill growth and reproduction depend on the amount of energy available after the costs of baseline maintenance have been met (Constable and Kawaguchi, 2018). Our findings indicate that warming Southern Ocean waters are likely to increase routine metabolic rate of krill at temperatures $>3.5{ }^{\circ} \mathrm{C}$ (Fig. 4a), suggesting increases and/or shifts in process-specific energy demands which impose energetic constraints on growth at temperatures $\geq 3.5^{\circ} \mathrm{C}$ (Fig. 4b). A limitation in food intake and/or conversion at higher temperatures may have contributed to the temperature-dependent decline in growth observed here, especially pronounced after the onset of the reproductive period. The effects of temperature on krill growth observed here suggest that krill will become progressively smaller (and lighter) in the future, especially if temperatures reach $3.5{ }^{\circ} \mathrm{C}$ within a broad distributional range (Fig. 4b). Furthermore, as the major temperature effects became mostly evident during the spawning season and thereafter, this may imply that the energetic requirements during this time of the year may leave krill particularly sensitive to the effects of temperature on whole animal level. Temperature effects on individual growth and thus, total biomass as well as on parental krill fitness due to increased energetic demands may subsequently affect reproductive capacities (Cuzin-Roudy, 2000; Tarling et al., 2007), which directly relates to future population dynamics. It may also have an impact on total biomass available for predators and fisheries in the future (Wiedenmann et al., 2008). Predicted changes in food quality and quantity in the Southern Ocean (Deppeler and Davidson, 2017) may exacerbate the effects of temperature demonstrated here. Due to the strong seasonality of the Southern Ocean, krill generally has a short timeframe where energy for 
growth and reproduction can be accumulated and its life cycle is timed closely to this highly seasonal environment (Meyer et al., 2010a; Teschke et al., 2011; Meyer and Teschke, 2016). Any changes in food quantity/quality but also availability during the time of the year needed, e.g. due to temporal shifts in seasonal timings of bloom patterns, may therefore have an additional impact on krill performance in the future. However, the validity and the sign of these impacts remain to be investigated, especially with respect to their effectiveness in the field.

We still lack a complete mechanistic understanding of the effects of temperature on krill physiology. Additional, process-oriented studies are urgently needed to be able to quantify the thermal sensitivity and the respective energy budget shares of physiological processes under future Southern Ocean temperatures. In addition, future changes in environmental factors will act in a complex and simultaneous manner on the whole ecosystem. The capacity to acclimatize and/or migrate, limited by geography (e.g. coastal boundaries) and ecological factors (e.g. temperature, habitat/food availability and quality) will therefore define future distribution ranges of this species (Peck et al., 2010; Hill et al., 2013; Veytia et al., 2020).

\section{Conclusions}

The long-term acclimation of E. superba at different temperature scenarios provided insights into the effects of elevated ambient temperatures on Antarctic krill during austral summer. Our data do not only provide a more detailed insight into krill (thermal) physiology on the whole animal level but also allow a first determination of the capacity of Antarctic krill to cope with Southern Ocean warming. Although the highest temperatures - eliciting the largest effects - represent rather unrealistic habitat scenarios, we were able to refine preliminary thermal thresholds for important krill life cycle traits. The results obtained here will help to refine existing models and emphasize the need for additional studies, in the laboratory as well as in the field. In turn, this will allow for realistic, model-based predictions of krill abundances and biomass under predicted Southern Ocean warming scenarios. Future studies should concentrate on the underlying physiological processes involved in the observed responses, in particular on the thermal sensitivities of the different fractions contributing to the krill energy budget, and downstream effects on reproductive capacity.

\section{Declaration of Competing Interest}

All authors declare no conflict of interest.

\section{Acknowledgements}

The staff of the krill aquarium at the Australian Antarctic Division (namely Robert King, Tasha Waller, Ashley Cooper, Blair Smith and Melanie Evans) is highly acknowledged for their advice and major assistance with the maintenance and sampling of Antarctic krill during the long-term experiment. We are also indebted to Marvin Dörries for his assistance during the second respiration measurement campaign as well as Lloyd S. Peck for his advice on the experimental design. A sincere thank you to Ryan Driscoll for the diligent grammar and spelling check of the manuscript.

This work was funded by the project PEKRIS (FKZ 03F0746A) of the German Ministry for Education and Research (BMBF) and Australian Antarctic Program Project \#4037.

\section{Appendix A. Supplementary data}

Supplementary material related to this article can be found, in the online version, at doi:https://doi.org/10.1016/j.zool.2021.125910.

\section{References}

Atkinson, A., Siegel, V., Pakhomov, E., Rothery, P., 2004. Long-term decline in krill stock and increase in salps within the Southern Ocean. Nature 432, 100-103. https://doi. org/10.1038/nature02996.

Atkinson, A., Shreeve, S., Hirst, A.G., Rothery, P., Tarling, G.A., Pond, D.W., Korb, R.E., Murphy, E.J., Watkins, J.L., 2006. Natural growth rates in Antarctic krill (Euphausia superba): II. Predictive models based on food, temperature, body length, sex, and maturity stage. Limnol. Oceanogr. 51, 973-987.

Atkinson, A., Hill, S.L., Pakhomov, E.A., Siegel, V., Reiss, C.S., Loeb, V.J., Steinberg, D.K., Schmidt, K., Tarling, G.A., Gerrish, L., Sailley, S.F., 2019. Krill (Euphausia superba) distribution contracts southward during rapid regional warming. Nature Climate Change 9, 142-147. https://doi.org/10.1038/s41558-018-0370-z.

Bopp, L., Resplandy, L., Orr, J.C., Doney, S.C., Dunne, J.P., Gehlen, M., Halloran, P., Heinze, C., Ilyina, T., Séférian, R., Tjiputra, J., Vichi, M., 2013. Multiple stressors of ocean ecosystems in the 21st century: projections with CMIP5 models. Biogeosciences 10, 6225-6245. https://doi.org/10.5194/bg-10-6225-2013.

Brown, M., Kawaguchi, S., Candy, S., Virtue, P., 2010. Temperature effects on the growth and maturation of Antarctic krill (Euphausia superba). Deep Sea Research Part II: Topical Studies in Oceanography 57, 672-682. https://doi.org/10.1016/j. dsr2.2009.10.016.

Brown, M., Kawaguchi, S., Candy, S., Yoshida, T., Virtue, P., Nicol, S., 2013. Long-term effect of photoperiod, temperature and feeding regimes on the respiration rates of Antarctic krill (Euphausia superba). Open Journal of Marine Science 03, 40-51. https://doi.org/10.4236/ojms.2013.32A005.

Buchholz, F., 1991. Moult cycle and growth of Antarctic krill Euphausia superba in the laboratory. Marine Ecology Progress Series 69, 217-229.

Buchholz, F., 2003. Experiments on the physiology of southern and northern krill, Euphausia superba and Meganyctiphanes norvegica, with emphasis on moult and growth - a review. Marine and Freshwater Behaviour and Physiology 36, 229-247. https://doi.org/10.1080/10236240310001623376.

Buchholz, F., Saborowski, R., 2000. Metabolic and enzymatic adaptations in northern krill, Meganyctiphanes norvegica, and Antarctic krill, Euphausia superba. Can. J. Fish. Aquat. Sci. 57, 115-129.

Cascella, K., Jollivet, D., Papot, C., Leger, N., Corre, E., Ravaux, J., Clark, M.S., Toullec, J. Y., 2015. Diversification, evolution and sub-functionalization of 70kDa heat-shock proteins in two sister species of Antarctic krill: differences in thermal habitats, responses and implications under climate change. PLoS One 10, e0121642. https:// doi.org/10.1371/journal.pone.0121642.

Clarke, A., Morris, D.J., 1983. Towards an energy budget for krill: The physiology and biochemistry of Euphausia superba Dana. Polar Biology 2, 69-86.

Constable, A.J., Kawaguchi, S., 2018. Modelling growth and reproduction of Antarctic krill, Euphausia superba, based on temperature, food and resource allocation amongst life history functions. ICES Journal of Marine Science 75, 738-750. https://doi.org/ 10.1093/icesjms/fsx190.

Cuzin-Roudy, J., 2000. Seasonal reproduction, multiple spawning, and fecundity in northern krill, Meganyctiphanes norvegica, and Antarctic krill, Euphausia superba. Can. J. Fish. Aquat. Sci. 57, 6-15.

de Santana, C.N., Rozenfeld, A.F., Marquet, P.A., Duarte, C.M., 2013. Topological properties of polar food webs. Marine Ecology Progress Series 474, 15-26. https:// doi.org/10.3354/meps10073.

Deppeler, S.L., Davidson, A.T., 2017. Southern Ocean phytoplankton in a changing climate. Frontiers in Marine Science 4. https://doi.org/10.3389/fmars.2017.00040.

Flores, H., Atkinson, A., Kawaguchi, S., Krafft, B.A., Milinevsky, G., Nicol, S., Reiss, C., Tarling, G.A., Werner, R., Bravo Rebolledo, E., Cirelli, V., Cuzin-Roudy, J., Fielding, S., van Franeker, J.A., Groeneveld, J.J., Haraldsson, M., Lombana, A., Marschoff, E., Meyer, B., Pakhomov, E.A., Van de Putte, A.P., Rombolá, E., Schmidt, K., Siegel, V., Teschke, M., Tonkes, H., Toullec, J.Y., Trathan, P.N., Tremblay, N., Werner, T., 2012. Impact of climate change on Antarctic krill. Marine Ecology Progress Series 458, 1-19. https://doi.org/10.3354/meps09831.

Hill, S.L., Phillips, T., Atkinson, A., 2013. Potential climate change effects on the habitat of Antarctic krill in the Weddell quadrant of the Southern Ocean. PLoS One 8, e72246. https://doi.org/10.1371/journal.pone.0072246.

Hirche, H.-J., 1984. Temperature and metabolism of Plankton - I. Respiration of Antarctic zooplankton at different temperatures with a comparison of Antarctic and Nordic krill. Comp Biochem Physiol 77A, 361-368.

IPCC, 2013. In: Stocker, T.F., Qin, D., Plattner, G.-K., Tignor, M., Allen, S.K., Boschung, J., Nauels, A., Xia, Y., Bex, V., Midgley, P.M. (Eds.), Climate Change 2013: The Physical Science Basis. Contribution of Working Group I to the Fifth Assessment Report of the Intergovernmental Panel on Climate Change. Cambridge University Press, Cambridge, United Kingdom and New York, NY, USA, p. 1535.

IPCC, 2019. Summary for policymakers. In: Pörtner, H.-O., Roberts, D.C., MassonDelmotte, V., Zhai, P., Tignor, M., Poloczanska, E., Mintenbeck, K., Alegría, A., Nicolai, M., Okem, A., Petzold, J., Rama, B., Weyer, N.M. (Eds.), IPCC Special Report on the Ocean and Cryosphere in a Changing Climate in press.

Kawaguchi, S., 2016. Reproduction and Larval Development in Antarctic Krill (Euphausia superba). In: Siegel, V. (Ed.), Biology and Ecology of Antarctic Krill. Springer International Publishing, Cham, pp. 225-246. https://doi.org/10.1007/978-3-31929279-3_6.

Kawaguchi, S., Candy, S.G., King, R., Naganobu, M., Nicol, S., 2006. Modelling growth of Antarctic krill. I. Growth trends with sex, length, season, and region. Marine Ecology Progress Series 306, 1-15.

Kawaguchi, S., Yoshida, T., Finley, L., Cramp, P., Nicol, S., 2007a. The krill maturity cycle: a conceptual model of the seasonal cycle in Antarctic krill. Polar Biology 30, 689-698. https://doi.org/10.1007/s00300-006-0226-2. 
Kawaguchi, S., King, R., Meijers, R., Osborn, J.E., Swadling, K.M., Ritz, D.A., Nicol, S., 2010. An experimental aquarium for observing the schooling behaviour of Antarctic krill (Euphausia superba). Deep Sea Research Part II: Topical Studies in Oceanography 57, 683-692. https://doi.org/10.1016/j.dsr2.2009.10.017.

Larsen, J.N., Anisimov, O.A., Constable, A., Hollowed, A.B., Maynard, N., Prestrud, P., Prowse, T.D., Stone, J.M.R., 2014. Polar regions. In: Barros, V.R., Field, C.B., Dokken, D.J., Mastrandrea, M.D., Mach, K.J., Bilir, T.E., Chatterjee, M., Ebi, K.L., Estrada, Y.O., Genova, R.C., Girma, B., Kissel, E.S., Levy, A.N., MacCracken, S., Mastrandrea, P.R., White, L.L. (Eds.), Climate Change 2014: Impacts, Adaptation, and Vulnerability. Part B: Regional Aspects. Contribution of Working Group II to the Fifth Assessment Report of the Intergovernmental Panel on Climate Change. Cambridge University Press, Cambridge, United Kingdom and New York, NY, USA, pp. 1567-1612.

Makarov, R.R., Denys, C.J., 1981. Stages of sexual maturity of Euphausia superba Dana. BIOMASS Handbook 11, p. 11.

Mauchline, J., 1980. Measurement of body length of Euphausia superba Dana. BIOMASS Handbook 4, p. 9.

McWhinnie, M., Marciniak, P., 1964. Temperature responses and tissue respiration in Antarctic Crustacea with particular reference to the krill Euphausia superba. In: Lee, M.O. (Ed.), Biology of the Antarctic Seas, pp. 63-72. https://doi.org/10.1029/ AR001p0063.

Melvin, J.E., Kawaguchi, S., King, R., Swadling, K.M., 2018. The carapace matters: refinement of the instantaneous growth rate method for Antarctic krill Euphausia superba Dana, 1850 (Euphausiacea). Journal of Crustacean Biology 38, 689-696. https://doi.org/10.1093/jcbiol/ruy069.

Meredith, M.P., King, J.C., 2005. Rapid climate change in the ocean west of the Antarctic Peninsula during the second half of the 20th century. Geophysical Research Letters 32. https://doi.org/10.1029/2005g1024042.

Meredith, M., Sommerkorn, M., Cassotta, S., Derksen, C., Ekaykin, A., Hollwed, A., Kofinas, G., Mackintosh, A., Melbourne-Thomas, J., Muelbert, M.M.C., Ottersen, G., Pritchard, H., Schuur, E.A.G., 2019. Polar regions. In: Pörtner, H.-O., Roberts, D.C., Masson-Delmotte, V., Zhai, P., Tignor, M., Poloczanska, E., Mintenbeck, K., Alegria, A., Nicolai, M., Okem, A., Petzhold, J., Rama, B., Weyer, N.M. (Eds.), IPCC Special Report on the Ocean and Cryosphere in a Changing Climate. In press.

Meyer, B., 2010b. Antarctic Krill, Euphausia superba, a model organism to understand the impact of global warming on the marine Antarctic ecosystem. Polarforschung 80, $17-22$.

Meyer, B., Teschke, M., 2016. Physiology of Euphausia superba. In: Siegel, V. (Ed.), Biology and Ecology of Antarctic Krill. Springer International Publishing, Cham, pp. 145-174. https://doi.org/10.1007/978-3-319-29279-3 4.

Meyer, B., Auerswald, L., Siegel, V., Spahic, S., Pape, C., Fach, B.A., Teschke, M., Lopata, A.L., Fuentes, V., 2010a. Seasonal variation in body composition, metabolic activity, feeding, and growth of adult krill Euphausia superba in the Lazarev Sea. Marine Ecology Progress Series 398, 1-18. https://doi.org/10.3354/meps08371.

Meyer, B., Atkinson, A., Bernard, K., Brierley, A., Driscoll, R., Hill, S., Marschoff, E., Maschette, D., Perry, F., Reiss, C., Rombola, E., Tarling, G., Thorpe, S., Trathan, P., Zhu, G., Kawaguchi, S., 2020. Successful ecosystem-based management of Antarctic krill should address uncertainties in krill recruitment, behaviour and ecological adaptation. Communications Earth \& Environment. https://doi.org/10.1038/ s43247-020-00026-1.

Ngan, P.V., Gomes, V., Carvalho, P.S.M., M.J.d.A.C.R. Passos, 1997. Effect of body size, temperature and starvation on oxygen consumption of Antarctic krill Euphausia superba. Revista Brasileira de Oceanografia 45, 01-10.

Nicol, S., Foster, J., 2016. The Fishery for Antarctic Krill: Its current status and management regime. In: Siegel, V. (Ed.), Biology and Ecology of Antarctic Krill. Springer International Publishing, Cham, pp. 387-421. https://doi.org/10.1007/ 978-3-319-29279-311.

Nicol, S., De La Mare, W.K., Stolp, M., 1995. The energetic cost of egg production in Antarctic krill (Euphausia superba Dana). Antarctic Science 7, 25-30. https://doi.org/ 10.1017/s0954102095000058.

Nicol, S., Virtue, P., King, R., Davenport, S.R., McGaffin, A.F., Nichols, P., 2004. Condition of Euphausia crystallorophias off East Antarctica in winter in comparison to other seasons. Deep Sea Research Part II: Topical Studies in Oceanography 51, 2215-2224. https://doi.org/10.1016/j.dsr2.2004.07.002.

Nicol, S., Foster, J., Kawaguchi, S., 2012. The fishery for Antarctic krill - recent developments. Fish and Fisheries 13, 30-40. https://doi.org/10.1111/j.14672979.2011.00406.x.

Opalinski, K.W., 1991. Respiratory metabolism and metabolic adaptations of Antarctic krill Euphausia superba. J Pol Arch Hydrobiol 38, 183-263.

Peck, L.S., 2005. Prospects for surviving climate change in Antarctic aquatic species. Front Zool 2, 9. https://doi.org/10.1186/1742-9994-2-9.

Peck, L.S., Morley, S.A., Clark, M.S., 2010. Poor acclimation capacities in Antarctic marine ectotherms. Marine Biology 157, 2051-2059. https://doi.org/10.1007/ s00227-010-1473-x.

Pinheiro, J., Bates, D., DebRoy, S., Sarkar, D., R Core Team, 2020. nlme: Linear and Nonlinear Mixed Effects Models, R package version 3.1-148. https://CRAN.R-pr oject.org $/$ package $=$ nlme.
Piñones, A., Fedorov, A.V., 2016. Projected changes of Antarctic krill habitat by the end of the 21st century. Geophysical Research Letters 43, 8580-8589. https://doi.org/ 10.1002/2016gl069656.

Poleck, T.P., Denys, C.J., 1982. Effect of temperature on the molting, growth and maturation of the Antarctic krill Euphausia superba (Crustacea: Euphausiacea) Under Laboratory Conditions. Marine Biology 70, 255-265.

Pörtner, H.O., 2010. Oxygen- and capacity-limitation of thermal tolerance: a matrix for integrating climate-related stressor effects in marine ecosystems. J Exp Biol 213, 881-893.

R Core Team, 2020. R: A language and environment for statistical computing. URL. R Foundation for Statistical Computing, Vienna, Austria. https://www.R-project.org/.

Rakusa-Suszczewski, S., Opalinski, K.W., 1978. Oxygen consumption in Euphausia superba. Polskie Archiwum Hydrobiologii 25, 633-641.

Reiss, C.S., 2016. Age, growth, mortality, and recruitment of Antarctic Krill, Euphausia superba. In: Siegel, V. (Ed.), Biology and Ecology of Antarctic Krill. Springer International Publishing, Cham, pp. 101-144. https://doi.org/10.1007/978-3-31929279-3_3.

Rensing, L., Ruoff, P., 2002. Temperature effect on entrainment, phase shifting, and amplitude of circadian clocks and its molecular bases. Chronobiol Int 19, 807-864. https://doi.org/10.1081/cbi-120014569.

Rhein, M., Rintoul, S.R., Aoki, S., Campos, E., Chambers, D., Feely, R.A., Gulev, S., Johnson, G.C., Josey, S.A., Kostianoy, A., Mauritzen, C., Roemmich, D., Talley, L.D., Wang, F., 2013. Observations: Ocean. In: Stocker, T.F., Qin, D., Plattner, G.-K., Tignor, M., Allen, S.K., Boschung, J., Nauels, A., Xia, Y., Bex, V., Midgley, P.M. (Eds.), Climate Change 2013: The Physical Science Basis. Contribution of Working Group I to the Fifth Assessment Report of the Intergovernmental Panel on Climate Change. Cambridge University Press, Cambridge, United Kingdom and New York, NY, USA.

Rintoul, S.R., Chown, S.L., DeConto, R.M., England, M.H., Fricker, H.A., MassonDelmotte, V., Naish, T.R., Siegert, M.J., Xavier, J.C., 2018. Choosing the future of Antarctica. Nature 558, 233-241. https://doi.org/10.1038/s41586-018-0173-4.

RStudio Team, 2020. RStudio: Integrated Development for R. RStudio, PBC, Boston, MA, USA. http://www.rstudio.com.

Schmidt, K., Atkinson, A., 2016. Feeding and food processing in Antarctic Krill (Euphausia superba Dana). In: Siegel, V. (Ed.), Biology and Ecology of Antarctic Krill. Springer International Publishing, Cham, pp. 175-224. https://doi.org/10.1007/ 978-3-319-29279-3 5.

Segawa, S., Kato, M., Murano, M., 1979. Oxygen consumption of the Antarctic krill. Transactions of the Tokyo University of Fisheries 3, 113-119.

Sokolova, I.M., 2013. Energy-limited tolerance to stress as a conceptual framework to integrate the effects of multiple stressors. Integr Comp Biol 53, 597-608.

Tarling, G.A., 2020. Routine metabolism of Antarctic krill (Euphausia superba) in South Georgia waters: absence of metabolic compensation at its range edge. Marine Biology 167. https://doi.org/10.1007/s00227-020-03714-w.

Tarling, G.A., Shreeve, R.S., Hirst, A.G., Atkinson, A., Pond, D.W., Murphy, E.J., Watkins, J.L., 2006. Natural growth rates in Antarctic krill (Euphausia superba): I. Improving methodology and predicting intermolt period. Limnol. Oceanogr. 51, 959-972.

Tarling, G.A., Cuzin-Roudy, J., Thorpe, S.E., Shreeve, R.S., Ward, P., Murphy, E.J., 2007. Recruitment of Antarctic krill Euphausia superba in the South Georgia region: adult fecundity and the fate of larvae. Marine Ecology Progress Series 331, 161-179.

Tarling, G.A., Hill, S., Peat, H., Fielding, S., Reiss, C., Atkinson, A., 2016. Growth and shrinkage in Antarctic krill Euphausia superba is sex-dependent. Marine Ecology Progress Series 547, 61-78. https://doi.org/10.3354/meps11634.

Teschke, M., Kawaguchi, S., Meyer, B., 2007. Simulated light regimes affect feeding and metabolism of Antarctic krill, Euphausia superba. Limnol. Oceanogr. 52, 1046-1054.

Teschke, M., Wendt, S., Kawaguchi, S., Kramer, A., Meyer, B., 2011. A circadian clock in Antarctic krill: an endogenous timing system governs metabolic output rhythms in the euphausid species Euphausia superba. PLoS One 6, e26090. https://doi.org/ 10.1371/journal.pone.0026090.

Veytia, D., Corney, S., Meiners, K.M., Kawaguchi, S., Murphy, E.J., Bestley, S., 2020. Circumpolar projections of Antarctic krill growth potential. Nature Climate Change 10, 568-575. https://doi.org/10.1038/s41558-020-0758-4.

Virtue, P., Nicol, S., Nichols, P.D., 1993. Changes in the digestive gland of Euphausia superba during short-term starvation: lipid class, fatty acid and sterol content and composition. Marine Biology 117, 441-448.

Whitehouse, M.J., Meredith, M.P., Rothery, P., Atkinson, A., Ward, P., Korb, R.E., 2008. Rapid warming of the ocean around South Georgia, Southern Ocean, during the 20th century: Forcings, characteristics and implications for lower trophic levels. Deep Sea Research Part I: Oceanographic Research Papers 55, 1218-1228. https://doi.org/ 10.1016/j.dsr.2008.06.002.

Wiedenmann, J., Cresswell, K., Mangel, M., 2008. Temperature-dependent growth of Antarctic krill: predictions for a changing climate from a cohort model. Marine Ecology Progress Series 358, 191-202. https://doi.org/10.3354/meps07350. 